\title{
Osmanlı Devleti'nde Geleneksel Oğuz Veraseti Üzerine
}

\section{Serhan ÇINAR}

\section{On Traditional Oghuz Inheritance in the Ottoman State}

Citation/C: Çınar, Serhan, (2017). On Traditional Oghuz Inheritance in the Ottoman State, Milel ve Nihal, 14 (1), 312-334.

Abstract: The Ottoman State had a well-established state hierarchy for 627 years. The legitimacy of the 0ttoman state administration is based on various sources. The most important of these is the tradition of Oğuz inheritance which symbolizes Turkish state organization. In this article, the concept of Turkish Cihan dominance in the Ottoman Empire was considered in a comprehensive way. In this context, the concepts in Old Turkish political life such as kut, töre, red apple, gaza, oghuz were emphasized. Also, the reflection of the Oguz culture on the Ottoman political culture has been researched.

Key Words: Ottoman concept of state, Turkish world domination, Oguzname, khan, sacred.

* Doktora Öğrencisi, Ankara Üniversitesi, Dil ve Tarih-Coğrafya Fakültesi, Genel Türk Tarihi Anabilim Dalı [serhancinar@mail.ru] 
Atıf/C): Çınar, Serhan, (2017). Osmanlı Devleti’nde Geleneksel Oğuz Veraseti Üzerine, Milel ve Nihal, 14 (1), 312-334.

Öz: Osmanlı Devleti, 627 yıllık köklü bir devlet hiyerarşisine sahiptir. Osmanlı Devlet yönetiminin meşruiyeti çeşitli kaynaklara dayandırılmaktadır. Bunlardan en önemlisi Türk devlet teşkilatlanmasını sembolize eden Oğuz veraset geleneğidir. Bu makalede Osmanlı Devleti'ndeki Türk Cihan hâkimiyeti düşüncesi kapsamlı bir şekilde ele alınmıştır. Bu bağlamda Eski Türk siyasal yaşantısında kut, töre, kızıl elma, gaza, Oğuzculuk gibi kavramlar üzerinde durulmuştur. Ayrıca Oğuz kültürünün Osmanlı siyasal kültürü üzerindeki yansımaları araştırılmıştır.

Anahtar Kelimeler: Osmanlı yönetim anlayışı, Türk cihan hâkimiyeti, Oğuzname, hakan, kutsal.

\section{Giriş}

Oğuzlar, Türk boyları arasında erken dönemde ulaşmış oldukları dünya nizam ülküleri sayesinde Türkistan havzasında kurulan birçok Türk devletinin mihenk noktasını oluşturmuşlardır. II. Göktürk devletinin yıkılmasıyla, batı Türkistan bölgesindeki Türk bakiyelerini kendi birlikleri etrafında toplayan Oğuzlar, başta Oğuz Yabguluğu olmak üzere; Peçenekler, Selçuklular, Harezimşahlar, Memlüklüler, Safeviler ve Osmanoğulları gibi Türk tarihine derin izler bırakmış birçok devlet kurmaya muvaffak olmuşlardır.

Tarihsel süreç içerisinde Oğuzların vücuda getirdikleri en büyük siyasi oluşum Osmanlı Devleti olmuştur. Osmanoğulları, kendi bünyelerinde kurmuş oldukları askeri ve bürokratik teşkilatlanmaları sayesinde yerküre üzerindeki birçok imparatorluktan daha geniş bölgeleri ele geçirebilmiş, üç kıtada birçok etnik grubu itâat altına alarak siyasi varlığını 624 yıllık asırlara uzanan bir döneme yaymıştır. Osmanlı Devleti'nin elde ettiği bu başarının altında; gelenekçi Türk devlet teşkilatlanma sisteminin tezahürleri, köklü İran bürokrasi geleneği ve Roma İmparatorluğundan devrşirilen yenilikçi uygulamaların tatbiki olduğu anlaşılmaktadır.

Osmanlı tarih araştırmalarında devletin temelini oluşturan ana etkenlerin neler olduğuna dair çeşitli araştırmacılar tarafından farklı kuruluş nazariyeleri ortaya atılmıştır. Biz bu araştırmamızda söz konusu bu nazariyeler üzerinden, Osmanlı meşruiyetinin kaynaklarını tespit etmeyi ve Osmanlı devlet yönetim ve teşkilatlanmasındaki geleneksel Oğuz veraseti uygulamalarının genel bir tablosunu çıkarmayı amaçlıyoruz. 


\section{Geleneksel Oğuz Tarihi Yazım Geleneği}

Oğuz boylarının siyasi tarihleri, devlet nizamları ve kültürleri hakkındaki bilgileri İslamiyet öncesi ve sonrası olmak üzere iki döneme ayrılmaktadır. İslam öncesi Oğuz kaynakları göçebe Oğuz boyları arasında sözlü olarak yaşatılan Oğuznameler ve Dede Korkud hikâyelerini kapsamaktadır. Söz konusu bu Oğuznamelerin içeriği incelendiğinde, Oğuzlar arasında erken dönem devlet veraseti, teşkilatlanma düsturu ve dünya cihangirlik ideallerinin işlendiği anlaşılmaktadır. Bu motifler, Oğuzların diğer Türk boylarına göre daha erken bir dönemde Türkistan havzasında siyasi birlik kurmalarını ve kısa sürede bir üst etnisite olarak Oğuz kimliğini oluşturmalarını sağlamıştır.

İslam öncesi dönemde Oğuzlara dair yazılı kayıtların varlığ1 Türk yazıtlarında geçen birkaç cümleden ve sözlü Oğuzname varyantlarından oluşmaktaydı. Oğuzlara dair milli tarih yazımının başlangıcı ise Oğuzların İslamiyet'i kabulünden sonraki süreçte Türkistan'da kurulan Oğuz kökenli Türk-İslam devletleri döneminde gerçekleşmiştir. İslami gelenekte kurulmuş olan bu yeni Türk devletleri, meşruiyetlerini geleneksel Türk devlet verasetine dayandırmak amacıyla tarihi Oğuznameler referansında çeşitli şecereler hazırlatmışlardır. Söz konusu bu Oğuznameler hakkında bilgi veren kaynaklar sırasıyla şunlardır:

Oğuznamelere ait sözlü ürünün ilk derlemesi, İlhanlı sarayının Yahudi bürokratlarından olan Reşidüddin'in, Cami'üt Tevarih ${ }^{1}$ adlı eserinde zikredilen Oğuz Kağan Destanı'dır. Bu eserde Oğuz boylarının cihanşümul hükümdarı olan Oğuz Han'ın efsanevi hayatı konu edinilmiştir. Rivayete göre; Oğuz Han, doğumundan başlayarak olağanüstü olaylara vakıf olan bahadır bir Oğuz beyinin oğludur. Gençlik çağında Yersub ve Gökkal adlı iki eşi olmuş ve bu eşlerinden toplam altı oğlu olmuştur. Bu oğullar sırasıyla; Gün Ay,

\footnotetext{
${ }^{1}$ Reşidüddin Fazlullah, Câmiü't Tevârih (Selçuklu Devleti),Çev. Erkan Göksu, Hüseyin Güneş, Selenge yay, İstanbul 2010, s. 7.
} 
Yıldız, Gök, Deniz, Dağ Han'dır. Kağanın veziri, hocası Irkıl'dır. Kıpçak onun üvey evladıdır. Yengi Kend² Oğuzların kurdurdukları efsanevi han otağıdır³. Oğuz Han tahta çıkıp kağanlığını ilan etmiş ve yerküre üzerinde Tanrı adına nizam ve adaleti sağlamak adına, Çin,Urum vb. birçok ülkeyi ele geçirmiş, ülke içerisindeki vassal devletlerin hukuki mevkilerini de bir nizâma bağlamış ve ele geçirdiği toprakları altı oğlu arasında taksim etmiştir. Bu taksim sırasinda feodal esaslara riayet edilirken aynı zamanda devlet içerisinde milli birliğin devam ettirilmesi amacıyla Oğuz'un her oğlundan doğan dört torunu ile çoğalan yirmi dört boy $i c ̧-d$ ış Oğuz veraseti doğrultusunda ve ok-yay hiyerarşisine göre birbirlerine tabi kılınmıştır. Tarihi Oğuz verasetine göre Üçoklar, Bozoklara tabiyetlerini birdirmiştirler"

Oğuzlar hakkında ayrıntılı bilgi veren bir diğer önemli eser, Kaşgarlı Mahmud'un Divânü Lügati't Türk adlı eseridir. Burada Oğuzlar 22 boy olarak gösterilmektedir ${ }^{5}$. İlerleyen yüzyıllarda Maveraünnehir bölgesinde Hokand Hanlığı kurulmuş, bu dönem milli Oğuz tarih yazıcılığg için mihenk noktasına dönüşmüştür. Nitekim kurulmuş ve bölgedeki Oğuz-Türkmen kalıntılarını hâkimiyetleri altına almışlardır. Hanlık bünyesinde bulunan Türkmen beyleri, Ebulgazi Bahadır'dan kendilerine ait milli bir tarih yazdırılmasını talep etmişler, Ebulgazi de bu doğrultuda Türkmen'lerin elinde bulunan Oğuzname ve şecereleri tasnif ve tahlil ederek Oğuzlara dair Şecere-i Terâkime ${ }^{6}$ adlı eserini kaleme almıştır. Söz konusu bu eserde Oğuz boylarına, Kaşgarlı'nın listesi haricinde iki boy eklenerek 24 boy olarak listelenmiştir. Bununla birlikte yine Reşidüddin'in listesinde de 24 boylu Oğuz tabiri geçtiğini bilmekteyiz.

\footnotetext{
${ }^{2}$ Yengi Kend için bkz Serhan Çınar, "IX-X. yy'da Sirderya Boyundaki Oğuz Şehirleri (Yengi Kend ve Farab Örneğinde)", Hitit Üniversitesi Sosyal Bilimler Enstitüsü, Yayımlanmamış Yüksek Lisans Tezi, Çorum 2016.

${ }^{3}$ Osman Turan, Türk Cihan Hâkimiyeti Mefküresi Tarihi, Ötügen yay, İstanbul 2013, s. 95.

${ }^{4}$ Zeki Velidi Togan, Oğuz Destamı (Reşideddin Oğuznâmesi Tercüme ve Tahlili, Enderun Kitabevi, İstanbul 1982,s.25-27.

${ }^{5}$ Kaşgarlı Mahmud, Divânü Lügat'it Türk, Çev. Besim Atalay, TTK, Ankara 2006,s.10.

${ }^{6}$ Ebulgazi Bahadır Han, Şecere-i Terâkime: Türklerin Soy Kütü̆̆̈̈, Çev. Muharrem Ergin, Tercüman yay, Kervan Kitapçılık, Konya 1974, s. 3.
} 
Oğuz tarih yazıcılığının ilk örnekleri olan söz konusu bu eserlerin yazılmasındaki asıl gaye, müelliflerin mensubu olduğu hanedanların siyasi meşruiyetlerini Oğuznamelere dayandırarak geleneksel Oğuz verasetinin baş mirasçısı konumuna gelme teşebbüsleri olduğu anlaşılmaktadır. Bu müelliflerden birincisi Kaşgarlı Mahmud olmakla birlikte müellif kendi döneminde Selçuklu hanedan mensuplarından Terken Hatun tarafından himaye edilmiştir. Selçuklu hanedanına siyasi bir meşruiyet kazandırmak amacıyla eserinde Oğuz şeceresinin başına tarihi Oğuz ananesine aykırı olmasına rağmen Üçoklardan Kınık boyunu yerleştirmiştir. Reşidüddin ise Osmanoğulları'nın hâkimiyetini kendi zamanında görmesi ve Selçuklulara karşı alternatif bir Oğuz veraseti yaratma çabasıyla, eserinde Türkçedeki $y-k$ değişiminden mütevellit, Oğuz hükümdarları olan Yavkuyları, (Yabgular) Kayı boyuna bağlayarak, onları Oğuz listesinin başına geçirmiştir7. Söz konusu bu Oğuzname silsilelerinden meşruiyet kazanma geleneği Anadolu'daki Türkmen feodal siyasi birliklerinde de tezahür etmiştir. Nitekim Akkoyunlu dönemi tarihçilerinden Ebubekir Tehranî, Kitab-ı-Diyarbekriye adlı tarih yazmasının giriş kısmında bulunan Oğuz şeceresinin başında Kayı ve Kınık boyları haricinde Akkoyunluların hâkim kitlesini oluşturan Bayındır boyunu ilk sıraya yerleştirmiştir.

\section{Osmanlı Devleti Kuruluş Nazariyeleri ve Meşruiyet Sorunu}

Kayılar, 1250 Kösedağ savaşından sonra Batı Anadolu coğrafyası ve Bizans sınırlarında Anadolu Selçuklu devletine bağlı olarak uç beyliği vazifesinde bulunmaktaydılar. 1290'lı yıllarda Selçuklu Sultanı Aleaddin Keykubat'ın ölümüyle birlikte Osman Bey, Karacahisar'ı ele geçirerek bağımsızlığını ilan etmiştir. Bu yeni siyasi oluşum kısa zamanda aşiretten beyliğe, beylikten devlete dönüşerek, II. Mehmed döneminde Konstantinopolis'i ele geçirmiş ve meşruiyetini çağdaşı olan bütün devletlere kabul ettirmiştir9. Osmanlı Devleti'nin bir asırlık kısa bir zaman diliminde cihanşümul bir yapıya

\footnotetext{
${ }^{7}$ Faruk Sümer, Oğuzlar(Türkmenler):Tarihleri-Boy Teşkilatı-Destanları, Türk Dünyası Araştırmaları Vakfı, İstanbul 1999, s. 229, 230.

${ }^{8}$ Fuzuli Bayat, "Sözlü Tarihten Destana, Destandan Oğuznâmelere", Oğuzlar: Dilleri, Tarihleri ve Kültürleri, V. Uluslararası Türkiyat Araştırmaları Sempozyumu Bildirileri, Ankara 2015, s. 289.

${ }^{9}$ Cemal Kafadar, İki Cihan Arefesinde: Osmanlı Devleti'nin Kuruluşu, Çev. Ceren Çırkın, Editör. Mehmet Öz, Birleşik yay, İstanbul 2010, s. 203.
} 
dönüşmesindeki başlıca amiller devlet bürokrasisinin, her dönemin şartlarına göre şekillenebilen hiyerarşik yapısı ve devralmış olduğu Selçuklu, Bizans ve İran mirasını güzel bir şekilde harmanlayabilmesi olarak açıklanabilir. Osmanlı kuruluş döneminde görülen bu zengin ve köklü miras geleneği, Osmanoğulları'nın meşruiyet kaynaklarının neler olduğuna dair Osmanlı tarihi araştırmacıları tarafından çeşitli görüşlerin ortaya çıkmasına neden olmuştur. Erken dönem Osmanlı, Bizans ve İlhanlı kronikleri üzerinden ortaya çıkarılan söz konusu bu nazariyelerde işlenilen tarihi meseleler genellikle Devleti Aliyye (Osmanlı Devleti)'nin meşruiyet kaynakları ve söz konusu Osmanoğulları'nın etnik menşelerinin tespiti konularını kapsamaktaydi.

Osmanlı tarihinin modern tarih yazıcılığındaki ilk araştırmaları bilindiği üzere Hammer ve Babinger tarafından gerçekleştirilmiştir. Bu dönemde gerçekleştirilen modern Osmanlı tarihi çalışmaları, kuruluş nazariyelerinden ziyade erken dönem Osmanlı kroniklerini tercüme teşebbüsleri olmuştur. Nitekim Hammer' da bu doğrultuda Osmanlı Devleti'nin sosyal, siyasi, kültür ve müesseselerini Osmanlı vakanüvislerinden aktardığı şekliyle eserine eklemiş ve onları tenkit süzgecinden geçirmemiştir. Hammer'in vakanüvislere duyduğu güven sebebiyle 10 ciltlik eserinde kuruluş dönemi problemleri ne dair sadece 40 sayfalık bir yer ayırdığ 1 anlaşılmaktadır ${ }^{10}$.

\section{a)Yeni bir Osmanlı Irkı Nazariyesi}

Modern dönem Osmanlı tarih yazıcılığında ilk defa menfi görüşünü açıklayan kişi, Amerikalı gazeteci ve ilahiyatçı H. A. Gibbons olmuştur. Müellif, "Osmanlı Imparatorluğu'nun Kuruluşu” adlı eserinde devletin kuruluşunda yabancı unsurların hâkim olduğunu görüşünü savunarak, Osman Bey'in gayrimüslim olan Cuk adlı bir çobanın veya Bizanslı Komnenoslar ailesinden ihtida etmiş bir prensin soyundan geldiğini düşünmektedir. Gibbons bu doğrultuda ortaya çıkan Osmanoğulları'nı ise bölgedeki gayr-i müslim ve göçebe

10 Yücel Öztürk, “Osmanlı Devleti'nin Kuruluşu Hakkında Bazı Görüşler”, Kuruluş ve Çöküş Süreçlerinde Türk Devletleri Sempozyumu Bildirileri, Sakarya Üniversitesi yay. No 52, Sakarya 2008, s. 196. 
Türkmen boylarının karışıp kaynaşmasından ortaya çıktığını ve Osmanlıların, köken olarak Türklükten ayrı yeni bir ırk olduğunu iddia etmektedir ${ }^{11}$

Gibbons'un ortaya attığ1 bu görüşünü özellikle Köse Mihal, Malkoçoğlu vb. Rum tekfurlarının aslen Bizans kökenli oldukları ve sonradan asimile olarak Müslüman oldukları üzerine kurgulanmıştır. Bilineceği üzere Osmanoğulları'nın kuruluş döneminde benimsemiş olduğu yöntem asimilasyon politikasından ziyade, İran kaynaklı hoşgörü, adalet ve denge sistemi üzerine kurulmuştu ${ }^{12}$. Gibbons'un nazariyesi ayrıntısıyla irdelendiğinde, erken dönemde Osmanlı saflarına geçmiş olan Rum tekfurlarının asimile edilmesi mümkün gözükmüyordu. Zira XIV. yy Bizans ve İlhanlı kaynaklarından, Marmara bölgesindeki Türk popülasyonunun, Rum vb. yerel kalıntılardan daha az olduğu anlaşılmaktadır. Ayrıca söz konusu Rum tekfurlarının Müslüman-Gazi kimliklerine bürünmelerinde menfi çıkarların daha fazla etkili olduğu anlaşılmaktadır. Nitekim söz konusu Rum tekfurlarının, ilerleyen dönemde Osmanoğulları tarafından bölgede oluşturulacak yeni siyasi oluşumlara katılarak, Bizans'a karşı daha fazla pay alabilme gayeleri güttüklerini düşünebiliriz ${ }^{13}$.

\section{b) Gaza Teorisi}

Alman tarihçilerinden P. Wittek, Osmanlı imparatorluğunun kuruluşunu Haçlılar bağlamında incelemiş ve Gibbons'tan ayrılarak devletin kuruluş felsefesini, Bizans faktörü değil aksine İslamiyet'in dârülharp bölgelerinde yayılmasını düstur edinen "gaza ideolojisi" ne bağlamıştır. P. Wittek'e göre ilk dönem Osmanlı hanedan

\footnotetext{
${ }^{11}$ Mehmet Öz, Oktay Özel, Söğüt'ten İstanbul'a, İmge yay, 2011, s. 33, Yücel Öztürk,"a.g.m, s. 208, 215.

${ }^{12}$ Burada Osmanlı Devleti'nin kuruluş döneminde "denge" sistemi olarak adlandırılan ve Pers-İran menşeli devlet yönetim sisteminin özünde "Devleti denetlemek için büyük bir ordu gerekir. Orduyu beslemek için çok mal ve servete ihtiyaç vardır. Bu serveti elde etmek için halk zengin olmalıdır. Halkın zengin olmast için de yasalar adil olmalıdır. Bunlardan biri ihmal edilirse devlet yıkılır" düsturu benimsenmiştir bkz Halil İnalcık, Osmanlı İmparatorluğu Klâsik Çağ (1300-1600) Çev. Ruşen Sezer, Yapı Kredi Yay, İstanbul 2004, s. 71, 73.

${ }^{13}$ Köse Mihal-Osman Bey ilk dönem ilişkileri hakkında "Biz bu vilâyete garip geldik; bunlar bizi hoş tuttular. İmdi bize vaciptir ki bunlara hürmet edelüm." bkz Osman Turan, Türk Cihan Hâkimiyeti Mefküresi Tarihi, s. 235.
} 
üyelerinin birçoğunun devlet yöneticisinden ziyade birer gaza koordinasyonunu sağlayan kişiler olarak kabul edilmelidir. Wittek, gaza düsturuna destek olarak da Orhan Gazi'nin Bursa'yı fethinden sonra 1337 tarihli bir câmi kitabesinde Osmanlı hükümdarlarının unvan ve sifatlarını "Gaziler Sultanın Oğlu Sultan, Gazi oğlu gazi, Ufukların Beyi" olduğunun altını çizmektedir. Müellif, kendi döneminde Türk tarih yazımında Osmanlı hanedanını Oğuz-Kayı kökenine bağlanmasına şüpheyle bakmaktadır. Nitekim Kaşgarlı Mahmud'un, Oğuz Kağan Destanı esasında mevcut olmayan ve kendisi tarafından bazı boyların listeye eklendiğini düşünmektedir. Ayrıca Osmanlı döneminde hazırlanmış olan 52 isimlik Oğuz şeceresinin ancak 21'inin gerçek olduğunu, 31' inin ise sonradan uydurulduğu görüşündedir ${ }^{14}$.

Wittek, Gibbons'un üzerine bütün nazariyesini inşa ettiği 400 çadır efsanesini reddederek Osmanlı Devleti'nin açıkça bir Rum Sultanlığı olduğunu iddia etmektedir. Yazar bununla birlikte Kayı geleneğinin Osmanlıların tarihine sonradan eklendiği fikrini açık şekilde savunmaktadır. Müellif, Oğuz/Kayı kökeni hakkında Yazıcıoğlu Ali'nin Türkçeye uyarladığı Selçukname'den itibaren Osmanlılar arasında Kayı geleneğinin yerleştiğini belirterek, ilk kroniklerdeki bir taraftan Oğuz'un büyük oğlu Gökhan'a diğer taraftan Günhan'a (Günhan'ın oğlu Kayı idi) bağlanan iki şecerenin birbiriyle çeliştiğine dikkat çekmektedir.

Wittek bununla birlikte Osmanlı Devleti içerisindeki ilk romantik teşebbüslerin II. Murad döneminde başladığını belirtmektedir. Wittek'in belirtmiş olduğu söz konusu bu teşebbüslerden, ilerleyen dönemlerde Osmanlı Devleti'nin çehresini Türk kökenli milli bir çizgiye çekilmeye çalışılacaktır ${ }^{15}$.

Bir diğer Osmanlı tarihçilerinden olan Colin Imber ise P.Wittek'in görüşüne karşı olarak Osmanlı'nın kuruluş dönemi gaza hareketlerindeki ilham ve disiplini, İslam şeriat hukukuna değil, evliyalık telakkisine dayandırıyordu ${ }^{16}$. Nitekim XIV. yy gazilerinin

\footnotetext{
14 Orhan Fuad Köprülü, “Osmanlı Devleti'nin Kuruluş ve Gelişmesindeki İtici Güçler", Osmanlı (Siyaset), s. 158, Yücel Öztürk, a.g.m, s. 215.

${ }^{15}$ M. Fuad Köprülü, Osmanlı'nın Etnik Kökeni, Kaynak yay, İstanbul 1999,s.74,

Yücel Öztürk, a.g.m, s. 204.

${ }^{16}$ Mehmed Öz, Oktay Özel, Söğ̈̈̈t'ten İstanbul'a, s. 36-37.
} 
dini ilhamları, İslam hukuk âlimi ulemasının belirlemiş olduğu şeriat düsturuna göre değil, ilk Osmanlı kroniklerinde sıklıkla görünen Türk kökenli sufi ve dervişleri referans almaktaydı. Örnek olarak "Aydos Kalesi hâkimi Rum tekfurunun kızı Peygamber'i rüyasında gördükten sonra babasının sarhoşluğundan yararlanarak kale kapıların gazilere açıyor. Diğer bir rivayette göre, "Bir derviş tahta kıllı̧ ile kâfirleri ortadan ikiye ayırmaktadır". Kuruluş dönemi hakkında bilgi veren erken dönem Osmanlı kroniklerinin hemen her hadisede bu tür mucizelerin konu edinmesi ilgi çekicidir ${ }^{17}$.

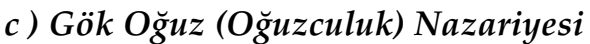

Mehmed Fuad Köprülü, Osmanlı Devleti'nin kökenini Gaza, Ahi mefhumlarından ziyade Gök-Oğuz telakkisine dayandığını belirtmektedir. Gök-Oğuz görüşü, Osmanlıları Oğuz Kağan nesline ve Oğuz dünya hâkimiyet telakkisine uygun, Selçukluların devamı olarak nitelendirilen Kayı'lara dayandırma geleneğidir. Köprülü, Osmanlıların Kayı geleneğine önem vermesini aniden uydurulmuş bir şey değil aksine mevcut bir geleneğin canlandırılması olduğuna vurgu yapmışt1 ${ }^{18}$. Gök-Oğuz görüşünün temelinde Osmanlıların ırki dayanak olarak aşireti benimsese de, dünya görüşü olarak Türk kozmik cihan telakkisini esas alması itibariyle üniversal bir açılıma sahip olduğu anlaşılmaktadır ${ }^{19}$. Köprülü'ye göre, Selçuklu ve Osmanlı dönemlerinde ahilik ve Sufizm adlarıla İslami bir karakter kazanan mistik din telakkisinin arka planında eski Türk ananesinin yer almaktay$d \imath r^{20}$.

\footnotetext{
${ }^{17}$ Erkan Göksu, “Osmanlı Devletinin Kuruluşunda Gaza ve Türkmen(Oğuz) Ananelerinin Rolü Üzerine", Oğuz Geleneği Çerçevesinde Tarihten Günümüze Karakeçililer, Ed. İsmail Özçelik, Kırıkkale 2003, s.27, Yücel Öztürk, a.g.m, s. 212212.

${ }_{18}$ Colin. J. Heywood, "Osmanlı Devletinin Kuruluş Problemi Yeni Hipotez Hakkında Bazı Düşünceler", Osmanlı(Siyaset), Ankara 1999, s.128,139, M. Fuad Köprülü, a.g.e, s. 58.

19 Yücel Öztürk, "Osmanlı Devleti'nin Kuruluşu Hakkında Bazı Görüşler", s. 208.

${ }^{20}$ M.Fuad Köprülü, “Osmanlı İmparatorluğunun Etnik Menşei Meseleleri”, Belleten, C. VII/28, TTK Ankara, 1943, s. 225-226.

Yücel Öztürk, a.g.e, s. 208.
} 
Halil İnalcık'ta Gök Oğuz nazariyesine uygun olarak Osmanlı'nın kuruluş aşamasındaki bu sürçte başlıca üç temel etmene işaret etmektedir: Birincisi, Oğuzların Anadolu'ya yaptıkları yoğun göç hareketleri, ikincisi, Türk- İslâm gaza hareketinin etkisi ve son olarak Denizli, Antalya, Ayasoluk ve Bursa'nın o tarihlerde milletlerarası pazar durumuna gelerek, Türkiye'nin dünya ticaret yollar üzerindeki önemini artırmasiyd $\imath^{\prime \prime 21}$.

Zeki Velidi Togan ise İnalcık ve Köprülü'nün Kayı boyu ile ilgili ileri sürdükleri fikirleri ayrıntılı bir tahlil ve reddiye sürecinden sonra Osmanoğulları'nın Kayı boyuna mensup olmadığını, söz konusu bu boyun Oğuzlarla birlikte Anadolu'ya gelen Tatar boylarından meydana getirilmiş olabileceğini düşünmektedir ${ }^{22}$. Oğuz ve Türkmenler üzerine önemli çalışmaları bulanan F. Sümerde, Osmanoğulları'nın Kayılarla olan irtibatının hayli zayıf olduğunu düşünmektedir. Faruk Sümer, kuruluş döneminde Vefai tarikatı mensubu olan Şeyh Edebali'ye devlet bünyesinde verilen imtiyazları belirtmiş, buna rağmen Kayı'ların Batı Anadolu'daki akrabaları olan Karakeçili vb. boylara II. Abdülhamid dönemine kadar hiçbir şekilde bir bağlantının kurulmamış olduğunu belirtmektedir ${ }^{23}$.

\section{III. İlk Dönem Osmanlı Kroniklerinde Oğuz-Türkmen İmgeleri}

Osmanlı dönemi erken dönem kroniklerinin birçoğunda Kayı'ların geleneksel Oğuz ananevisi doğrultusunda yazılmış olan gazavet ve menakıpnameleri, devlet bünyesinde sinırlı sayıda da olsa bulunmaktadır. Özellikle kuruluş ve yayılma döneminin erken safhaları Osmanlı tarihçilerinin kaynak sıkıntısı çektiği bölümlerin en başında gelmektedir ${ }^{24}$. Nitekim bu meselenin oluşmasındaki en büyük etken, şüphesiz Timurîlerin, Ankara savaşı öncesi ve sonrasında Anadolu'da uyguladıkları tahribat olarak karşımıza çıkmaktadır. Erken dönem Osmanlı kroniklerinin yazılış amacı, Osmanlıların kapısında yetişen kulların sadakat, korku ve çekinme duygularını

\footnotetext{
${ }^{21}$ Halil İnalcık, Osmanlı Imparatorluğu Klâsik Çă̆, s.70,71, Mehmed Öz, Oktay Özel, a.g.e, s. 225, 226.

22 M. Fuad Köprülü, a.g.e, s. 18, 19.

${ }^{23}$ Faruk Sümer, "Kayı", İslam Ansiklopedisi, C.XXV, TDVA, Ankara 2002,

s.77,78, Faruk Sümer, Ŏguzlar Türkmenler, s. 236,238.

${ }^{24}$ Halil İnalcık, "OsmanlıTürk Tarihçiliği Üzerine Notlar”,Çev. Bülent Arı, Uluslararası Askeri Tarih Dergisi, yay No: 19, Ankara 2007, s. 214,215.
} 
kuvvetlendirmekti. Söz konusu bu kroniklerde kendi yaşadıkları döneme kadar olan Osmanlı tarihinin kronolojisini açıklamaktaydılar. Bu kroniklerin genel üslubunda ağdalı bir İslamî motifler eserlere işlenmiştir. Bu üslubu özellikle kullanan, kaleme alınan eserlerin birçoğunun müellifinin ulema sınıfına mensup İslami medrese eğitimi almış kişilerden oluştuğu anlaşılmaktadır ${ }^{25}$.

I. Bayezid'e sunulduğu düşünülen Ahmedî'nin İskendernâmesine Osmanlı kuruluş sürecinde Sultan Alaeddin'e yardım edenler arasında Gündüz Alp ve Ertuğrul'un olduğu, Gök Alp ve Oğuz'dan çok kişinin de birlikte bulunduğu yazılıdır. Bu eserin hangi dönemde yazıldığı ve kime sunulduğu hakkında çeşitli ihtilaflar vardir ${ }^{26}$.

II. Murad döneminde Osmanlı Türkçesi, Gök-Türk, Uygur, Karahanlı devri kültür dili, ilk İslâmî Kur'an tercümeleri ve Türkçe eserleri ile gelişen bir yazı dilinin son halkasını teşkil etmekle beraber, Orta Asya ananesi kesilmiş, onun yerine Anadolu'da başlayan edebiyat ve kültür dili yine de bu temel üzerinde kurulmuştu ${ }^{27}$. II. Murad özellikle kendi döneminde Anadolu' daki Timur tahribatının izlerinin silinmesi ve Moğol bağlllı̆̆ından Türkmen/Oğuz geleneğine yönelmek ve Anadolu Türkmen Beylikleri üzerindeki Osmanlı meşruiyetinin yeniden pekiştirilmesi amacıyla kendi döneminde hanedanının Oğuzhan- Hz Nuh'a dayanan şecereler hazırlatılması istenilmiştir. Bu doğrultuda çeşitli eserler hazırlanmıştır ${ }^{28}$. Bunlar sırasiyla;

Baba İlyas'ın torunlarından Aşıkpaşazâde, II. Murad'ın isteği üzerine Tevârih-i Âl-iadlı eserini kaleme almıştır. Bu eser, esasen tercüme olmakla birlikte İbn Bibi'nin el-Evamirü'l Alaiye adlı kitabına

\footnotetext{
${ }^{25}$ Haldun Eroğlu, Osmanlılar: Devlet ve Hâkimiyet, Bilge Kültür Sanat yay, İstanbul 2016, s. 13-14-25, M.Fuad Köprülü, İslam ve Türk Hukuk Araştırmaları ve Vakıf Müessesesi, Akçă̆ yay, Ankara 2005, s. 25.

${ }^{26}$ Mehmet Öz, "İlk Osmanlı Kroniklerinde Oğuz Türkmen İmgesi”, Oğuzlar; Dilleri, Kültürleri, Tarihi, V. Hacettepe Türkiyat Araştırmaları Sempozyumu, Ankara 2015, s.378.

${ }^{27}$ Osman Turan, Türk Cihan Hâkimiyeti Mefküresi Tarihi, s. 254-256.

${ }^{28}$ Feridun Emecen, "Kayılar ve Osmanlılar: Sahte Bir Kimlik İnşası mı”,s. 208.
} 
dayandırılarak, ekleme ve çıkarmalar yapıldığı anlaşılmaktadır² Eserde, Selçukoğulları anlatılırken Oğuz boylarının onlara tabiolduğu vurgulanır. Aşıkpaşazâde Türk kavramını Osmanlılar için çeşitli bağlamlarda kullanır. Ertuğrul Gazi'yi Oğuz Han oğullarından Gök Alp'e bağlar. Âşıkpaşazâde, Osmanlıların atalarına Türk denildiğini, bunların göçer evli olduklarını ve içlerinde Türkmen ve Tatarların bulunduğunu açıklamaktadır ${ }^{30}$. Bununla birlikte Âşıkpaşazade böyle bir eseri kaleme almasını kendisine salık verenlerin Vefâi tarikatına üye dervişlerin olduğunu, Şeyh Edebâli'nin kendi ailesinin, Osmanlı hanedanının ortaya çıkmasındaki rollerini öne çıkarmaya çalışan aynı tarikatın bir üyesi olduğunu ve Şeyh Edebali vasıtasıyla kendisi ve yoldaşlarını güçlendirmeye, meşrulaştırmaya çalıştığ 1 anlaşılmaktadır ${ }^{31}$.

Bu dönemde yine II. Murad'ın Karakoyunlu Cihanşah'a elçi olarak gönderdiği Şükrullah'ın Behçetüt-Tevarih'te zikrettiği anekdotlarda Türkmen-Oğuz köken birliği bilinci ve imgesinin yaygınlığının bir başka göstergesidir. Nitekim eserde Oğuz taifelerinin putperestinden Müslüman olanlarına, konar-göçerinden yerleşiğine kadar kapsamlı ve detaylı bir şekilde sınıflandırıldığı ve Türklük kavramının ve şuurunun fazlasıyla bulunduğu anlaşılmaktadir ${ }^{32}$.

II. Mehmed döneminde İstanbul'un fethedilip merkezi bir cihan devletinin esasları atıldıktan sonra makbul hükümdar motiflerinin oluşturulması için geleneksel Türk-Oğuz anânelerinin referans gösterildiği eserler kaleme alınmaya başlanmıştır. Bu gelenekten, özellikle II. Mehmed'in şehzadelerinden olan Cem Sultan tarafından Cam-ı Cem-ayin, Kayı ve Saltuknâme-eserleri kaleme alınmiştır ${ }^{33}$.

II. Bayezid dönemine gelindiğinde dönemin ulemalarından olan Neşrî’nin Kitâb-ı Cihan-nümâ adlı eserinde Oğuz-Türkmen im-

\footnotetext{
29 Erdal Taşbaş, “Klasik Dönem Osmanlı Tarih Yazarları ve Eserlerine Kısa Bir Bakış", Mediterranean Journal of Humanities, S. I/2, Antalya 2011,s. 216,218.

${ }^{30}$ Mehmet Öz, a.g.m, s. 378.

${ }^{31}$ Haldun Eroğlu, a.g.e, s. 22.

${ }^{32}$ Mehmet Öz, a.g.m, s. 377.

${ }^{33}$ Feridun Emecen, "Kayılar ve Osmanlılar", s. 209.
} 
geleri karşımıza çıkmaktadır. Müellif, Âşıkpaşazâde gibi gazi-dervişler zümresine mensup olmasına rağmen kaleme aldığı bu eserinde Oğuzculuk ve Türklük vurgusu fazlasıyla belirgindir. Nitekim Kitâb-ı Cihan-nümâ'da 24 Oğuz boyu mensuplarının Müslüman Türkler olduğunu aktarlmakta ve Oğuz taifelerinin Türkistan ve Maveraünnehir'den Mısır ve Mağrib'e uzanan coğrafyada sakin olduklarım zikredilmektedir. Neşrî bu eserinde Oğuzculuğun kapsayıcı ve içerici bir kavramı ve şuurunun bulunduğunu vurgulayıp, Türk taifelerini, putperestinden Müslüman olanlarına, konar-göçerinden yerleşiğine kadar detaylıca ayrımını yapmıştı ${ }^{34}$. Yavuz Sultan Selim döneminin ünlü Şeyhülislam'ı İbn Kemal(Kemalpaşazâde) başlangıç dönemlerinde, tıpkı kaynaklarını teşkil eden yazarlar gibi Osmanlıları Türk ve Türkmen olarak tavsif etmektedir. Müellifin Akkoyunlular ve Dulkadirliler için Türkmân tabirini kullandiğ 1 anlaşılmaktadır ${ }^{35}$.

Hoca Saadeddin Efendi, III.Murad dönemi tarihçilerinden olup, Tacü't Tevarih adlı eserinde Osmanlı Devleti'nin kuruluşundan I. Selim'in ölümüne kadar ki Osmanlı tarihi ve ilk Osmanlı fetihlerinden bahsederken Osmanlı ordusu için "zaferleri gölge edinmiş Türk askerleri, savaş günleri yırtıcı arslan, Efrasyab gibi Türk yiğitleri" adlandırmalarını kullanmıştır ${ }^{36}$.

Yukarıdaki kroniklere ek olarak Osmanlı devlet yönetiminde sultanların meşruiyetlerini ekseriyetle İslami teoloji üzerine kurulmuş olsa da; Ahmedî'nin İskendernâme'si ile Dâstân ve Tevârih-i

\footnotetext{
${ }^{34}$ Neşrî, eserinde Sırpların Osmanlılara vergi göndermesini Sırp kralının ağzından "Türkler biz çıkışamazuz" diye ilçi gönderüp yılda bin cebelü ve ellibin vukıyye gümüş virecek oldu" ifadelerini eserinde aktarmaktadır. Müellif ayrıca I. Kosova savaşını tasvir ederken "Kafirler'den biri "Size gülerim zira hiç omren görmedim ki Türkü kâfir zincire veya ipe dize. Amma hemişe Türk gelir kâfirleri ipe ve zincire dizip alıp gider. Ve andan ki sonra Türk hergiz kâfir olmaz amma daim kâfirleri gelir, alır, gider Müslüman ider. Korkarm ki yine ol Türkler sizi kendi zincirinize ve iplerinize dizip, alıp, gide" sözleriyle Osmanlı kimliğinin ilk sırasında TürklükOğuzculuğun, İslam mefhumundan ön sırada yer aldığını aktarmaktadır. Bkz. Mehmet Öz, "Osmanlı Kroniklerinde Oğuz İmgesi”, s.378, Tufan Gündüz, a.g.m, s. 93-94.

${ }^{35}$ Mehmet Öz, , “ilk Osmanlı Kroniklerinde Oğuz Türkmen İmgesi”, s. 378.

${ }^{36}$ Tufan Gündüz, "Osmanlı Tarih Yazıcılığı'nda Türk ve Türkmen İmajı”, Osmanlı, Editörler: Kemal Çiçek-Cem Oğuz, c. VII, s. 92, Haldun Eroğlu, a.g.e, s. 17
} 
Mülûk-ı Âl-i Osman adlı eserlerinde, yine Enverî'nin Düstûrnâmesi'nde belirgin bir şekilde Oğuz gelenek ve göreneklerinin izleri görülmektedir. Osmanlı yönetiminde ve sosyal yapılanmasındaki Oğuz-Türk gelenekçiliği, Osmanlı gerileme döneminde bile eserlerde az da olsa kendisine yer bulmaktaydı. Nitekim XVIII. yüzyılda ki eserlerde dâhi "Padişâh-ı ruy-ı zemin zillullah-i fi'l-arz" anlayışına vurgu yapılmaktaydi ${ }^{37}$.

\section{Osmanlı Devlet Yönetiminde Oğuz Gelenekleri}

Osmanoğulları, Bizans sınır uçlarında kurmuş oldukları beylik, devlet ve cihanşümul bir imparatorluk olma yolunda bürokrasi ve teşkilatlanma yapılarını şüphesiz ki tek bir kaynaktan alınmamıştır. Bunlar içerisinde özellikle araştırmamıza konu olan Oğuz-Kayı anânelerinin klasik dönem Osmanlı yönetimine olan sirayetleri yadsınamayacak derecede fazladır. Osmanlı bürokrasi ve teşkilatlanmasındaki geleneksel Oğuz kaide ve anâneleri sırasıyla;

\section{a) Ă̆aç Kültü ve Rüya Efsaneleri:}

Ağaç kültü, Oğuz ve diğer Türk boyları arasında İslamiyet öncesi dönemde bereket getirildiğine inanılan efsanevi bir kült motifidir. Söz konusu bu motif, şekil itibariyle paganizmden izler taşımakla birlikte Oğuzlar tarafından kutsiyet atfedilmiştir. Nitekim Oğuz Kağan Destanına göre; İt Barak ülkesine doğru gerçekleştirdiği bir sefer sırasında Oğuz'un askerlerinden hamile kalan bir hatunun, ağaç içerisinde doğurduğu çocuğa Oğuz Kağan tarafından Kıpçak(ağaç özü-kovuğu) isminin verildiği bilinmektedir ${ }^{38}$. Tarihi Oğuznamelerde sıklıkla dünyanın merkezine konumlandırılan mitolojik tasavvurlu ağaç kültleri3 ${ }^{39}$, işlevselliği itibariyle Oğuz hükümdar

\footnotetext{
${ }^{37}$ Haldun Erdoğlu, “Osmanlıda İktidarın Değişim Süreci ve Meşruiyet Sorunu", Ankara Üniversitesi Dil ve Tarih Coğrafya Fakültesi Dergisi, S. 2, Ankara: 2004, s. 25.

38 Saadettin Gömeç, Türk Destanlarına Giriş, Berikan Yayınevi, Ankara, 2015, s. 66.

${ }^{39}$ Bu bilgiye örnek olarak günümüzde Kazakistan'ın başkenti Astana şehir merkezinde bulunan ve kadim Türk mitolojisinde bereket getirildiğine inanılan "Bayterek" adındaki hayat ağacı, Kazakistan'ın milli sembolleri arasında bulunmakla birlikte Kazak'lar için de günümüzde bolluk ve bereket simgesi olarak kabul görülmektedir.
} 
ailelerine meşruiyet kazandırılmak amacıyla sıklıkla kullanılan unsurlardan bir tanesiydi. Oğuzlar arasındaki söz konusu bu ağaç kült inanışları o denli derin ve köklü bir geçmişe sahip olmalıydı ki Türk boylarının ortaya çıkışına dair konu edilen mitlerde "ağaçtan yaratılma" veya "kayın ăgacı tarafından doğrulmuş olma" geleneği ve buna bağlı olarak kayın ağacının kutsal kabul edilmesi düsturu yaygınlaştıııld $1^{40}$. Ortaya çıkarılan bu geleneğin ise Türk boyları arasında Oğuzlar tarafından daha fazla benimsendiği anlaşılmaktadır. Nitekim günümüzdeki Oğuz dil ailesi grubuna mensup boylar arasında, kayın ağacının akrabalık ilişkilerinin kurulması amacıyla kullanıldığını, bu doğrultuda kayın-ata, kayın-baba tabirlerinin çok eski dönemlerden itibaren Oğuzlar arasında kullanılıyor olması ilgi çekicidir.

Söz konusu ağaç kültü, Oğuz boyları arasında ilk olarak Kınık boyu tarafından Horasan'da kurulan Selçuklu hanedanı mensuplarından Dukak' a atfedilmektedir. Efsanevi ağaç kültünün Selçuklu varyantına göre, Dukak rüyasında göbeğinden üç ağacın çıktığını ve bu ağaçların dallarının her tarafı sararak göklere yükseldiğini görmüştür. Dukak'ın bu kutlu rüyası, Dede Korkud tarafından tabir edildiğinde kendisine evlatlarının cihan sultanı olacağının müjdesi verilmiştir. Ağaç kültü motifi ilerleyen yıllarda milli Oğuz tarih yazıcılığının vazgeçilmeyen hükümdarlık âlametlerinden biri haline dönüşmüştür. Nitekim Osmanlı dönemi kuruluş efsaneleri arasında mevzu bahis bu ağaç kültünün Osmanlı dönemi varyantı da farklı şekilde karşımıza çıkmaktadır. Bu rivayete göre Osman Bey, Şeyh Edebali'nin zâviyesinde misafir iken Kur'an'ı çok ta'zîm etmesi sonucu, geceleyin rüyasında şeyhin kucağından çıkan bir ayın kendi koynuna girmesi ve Osman'ın göbeğinden çok muazzam bir ağaç yükselmesi ve bu ağacın dallarının bütün dünyayı sarması konu edinilmiştir ${ }^{41}$.

${ }^{40}$ Özkul Çobanoğlu, “Batı Sibirya Türk Kültürü Tetkiklerine Göre Kayın Ağac1nın Türk Mitolojisinde "Kutsal"laşmasının Maddi Kültürel Nedenleri" Orhon Yazıtlarının Bulunuşundan 120 Yıl Sonra Türklük Bilimi ve 21. Yüzyıl Konulu III. Uluslararası Türkiyat Araştırmaları Sempozyumu, Ankara 2010, s. 245-247.

${ }^{41}$ Osman Turan, a.g.e, s. 278. 


\section{b) Mitoloji ve Oğuz Hükümdar Sarayları:}

İslam öncesi kadim Türk kozmogonisine göre tanrıların sarayı, yeryüzünün merkezinde yer alan ve sıradağ silsileleriyle çevrili, iç denizlerin ortasında altın bir halka üstünde yükselen Altın Dağın zirvesinde tasavvur ediliyordu. İslami dönemde bu Altın Dağ motifinin yerini Kaf Dağın almıştır. Türk boylarındaki şehircilik faaliyetleri, tarihi Oğuznamelerde de sıklıkla karşımıza çıkan unsurlar arasındadır. Efsaneye göre, Oğuz Han çıktığı seferler sonrasında Türkistan'a dönmüş ve Aral Gölü çevresine geldiğinde buradaki eski bir şehri tamir ettirerek buranın yönetimine veziri Irkıl'1 vazifelendirmiştir. Tamir ettirilen söz konusu Yengi Kend (Yenişehir),ilerleyen dönemlerde Oğuz Yabguları tarafından orduğ (hükümdar sarayı) olarak kullanılmıştır. Oğuz bakiyesinden çıan Türk devlet başkentleri de Türk kozmogonosi düsturu doğrultusunda bulundukları bölgenin hâkim tepesine inşa edilme geleneği ortaya çıkmıştır ${ }^{42}$.

Selçuklular döneminde devam ettirilen söz konusu bu Oğuz şehircilik geleneği, Sencer Bey'in Türkmenistan'daki sarayı, Anadolu Selçuklularının başkenti olan Konya'daki suni Aleaddin Tepesi'nde karşımıza çıkmaktadır. Oğuz şehircilik geleneğinin Osmanlılardaki örneğini ise, II. Mehmed'in İstanbul'un fethinden sonra yaptırmış olduğu Topkapı Sarayında görmekteyiz. II. Mehmed, kurdurmuş olduğu bu yeni sarayını İstanbul'un yedi tepesine hâkim bir noktaya inşa ederek, kadim Türk kozmogonisinin birer tezahürü olan Altun Dağın zirvesinde bulunan Tanrı sarayları ile özdeşleştirmeyi amaçlamıştı. II. Mehmed'in ayrıca bu yeni sarayının bahçesine Türk mitolojisinde sonsuzluğu simgeleyen bir Çınar ağacını diktiği de bilinmektedir ${ }^{43}$.

\section{c) Geleneksel Kızıl Elma Kavramı}

Kadim Oğuz devletçilik geleneği içerisinden çıkan Kızıl Elma mefhumu, hedef, ülkü ve ulaşılması gerekilen menzil olarak adlandırılmış ve Oğuzlar ona sahip olmayı her daim canlı tutma gayesi olarak

\footnotetext{
${ }^{42}$ Emel Esin, "Ordu: Türk Saray Mimarisinin XV. Yüzylldan Önceki Tarihçesi",

TBMM Milli Saraylar Sempozyumu, C.1, Ankara Kasım 1984, s. 110,112

${ }^{43}$ Emel Esin, a.g.m, s. 110,112.
} 
belirlemişlerdir. Türk siyasi tarihinde Kızıl Elma ülküsünün dönem ve şartlara göre değişiklik gösterdiği anlaşılmaktadır.

Tarihsel süreç içerisinde Türk boyları arasındaki ilk ülkünün boyunduruğu altında bulundukları devletlere karşı giriştikleri bağımsızlık mücadelelerinde, komşu kavim ve devletler tarafından meşru bir zeminde tanınma gayesi olduğu anlaşılmaktadır. İlk Göktürk kağanı Bumın, henüz istiklal hareketine giriştiği ve yabgu unvanı taşıdığı bir zamanda, M.S. 545 yılında, kendilerine Çin elçisi gelince "bütün Türkler bununla devletlerinin yükseldiğine inanıyor ve birbirlerini tebrik ediyorlardı". Daha garbi Göktürklerin hükümdarı İstemi Han, Bizans İmparatoru Justinianus'a tarafından gönderilen Zemarkos adlı Bizans elçisi ile görüştüğü esnada Göktürk Yabgusunun gözlerinden yaş akar. Zemarkos bunun sebebini sorunca, İstemi: Atalarımızdan işittik ki Garp Imparatorluğu (Roma-Bizans)nun elçileri geldiği zaman bu, bizim için, artık yeryüzünü fetih ve istilâ edeceğimize delâlet eder" cevabı ile Türk boyları arasındaki cihan hâkimiyeti inancının çok eski dönemlerden beri mevcut olduğu ve böylece komşu kavimlere de yayıldığ 1 anlaşılmaktadır ${ }^{44}$.

Söz konusu Kızıl Elma mefhumu, Oğuzların İslamiyet'i kabulüyle farklı bir kimliğe dönüşerek Peygamberin hadis ve öğretileri doğrultusunda Konstantiniye ile özdeşleştirilmeye başlanmış, böylece Türk boylarının, özelliklede Oğuz taifelerinin yeni milli ülküsü haline dönüşmüştür. Oluşturulan bu yeni geleneğe göre: Ayasofya'nın önünde dikili bir sütün üzerinde, at üstünde bulunan Justinianus heykelinin bir elinde kızıl bir küre olup Türk Kızıl elması ve cihân hâkimiyetinin yeni hedefi olmuştur. Ortaya çıkarılan İslam kökenli bu yeni mefhum ileride fatih unvanını alacak olan II. Mehmed tarafından gerçekleştirilerek, Hz. Peygamberin hadis-i şerifine mazhar olunacaktır ${ }^{45}$.

\section{d) Hâkimiyetin Sembolü olarak Ok ve Yay Telâkkisi}

Tarihi Oğuznamelerde, Oğuz Han kendi belirlemiş olduğu töreye göre Oğuz dünya hakimiyetini kurduktan ve ihtiyarladıktan sonra devletini altı oğlu ile her oğlundan doğan dört torunu arasında bö-

\footnotetext{
${ }^{44}$ Osman Turan, a.g.e, s. 279.

${ }^{45}$ Osman Turan, a.g.e, s. 279.
} 
lüştürmüş, böylece geleneksel 24 boylu Türk-Oğuz feodal devlet verasetinin sınırları belirlenmiştir. Oluşturulan bu verasete göre Oğuzhan'ın üç oğlu olan, Gün, Ay ve Yıldız'dan olma on iki torunu (boy) sağ, Gök, Dağ ve Deniz'den olma on iki torunu da sol kolu teşkil eder. Oğuz han hâkimiyeti temsil eden yayı birincilere, tabiiyeti temsil eden oku da ikincilere vermiştir. Yani Üç-oklar, Boz-oklara tâbi kılınmıştır. Bu taksim tarihe İç-Dış Oğuz veraset sistemi olarak geçmiştir. Bu veraset geleneği Oğuzlar tarafından kurulan Selçuklu ve Osmanlı hanedanları tarafında da değiştirilmeden tatbik edilmiştir. Nitekim bu geleneksel Oğuz verasetinin örneklerine Büyük Selçuklular döneminde Tuğrul Bey'in, Bağdat'in fethi sonrasında Meseleme câmii mihrabına kendisine bağlllık nişanesi olarak ok ve yay işaretleri koydurduğu; yine Anadolu Türkmen Beylerinden Artuk'un, Kudüs'te Kıyâme (Resurection) kilisesi tavanına üç ok motifini yerleştirdiği; son olarakta Osmanlı'lar döneminde Evliya Çelebi, II. Mehmed'in bu geleneği sürdürerek İstanbul'un fethinden sonra âlametim olsun diye Ayasofya'nın kubbesine ok yerleştirdiği ve bunun kendi zamanında dahi oradan görüldügü zikredilmektedir ${ }^{46}$. Söz konusu bu ok-yay motiflerini Osmanlı dönemindeki hanedan üyeleri ok ve yayı şahsi imzaları olarak kullanmışlar ve buna tuğrâ adını verilmişlerdir. Bu hususta Kâşgarlı Mahmud, tuğranın "Ŏ̆uzlara mahsus olup diğer Türklerce bilinmediğini" aktarmaktadır ${ }^{47}$.

\section{e) Hükümdarlarnn Pederânelik Vasıflarn}

Eski Türk kağan ve sultanları semavi menşe ve cihan hâkimiyetine sahip bulunmak inancı ile milletin ve tebaanın velisi veya babası sayılıyor ve dünyanın efendisi sıfatlarını haiz bulunuyorlardı. Bu velilik sıfatı (velayet-i pederane, Oğuz Han ile veziri İrkil Hoca'ya atfolunmuş bir anane idi. Filhakika Oğuz Han dünyayı fethettikten sonra muhteşem bir altın çadır (otağ) kurdurdu; büyük bir toy hazirlattı. Destana göre 90.000 koyun, 700 kadar büyük baş hayvan kestirdi. Bütün hatunlar, beyler, kumandanlar ve halk bu toya katılmıştı. Oğuz Han bu büyük merasimde hâkimiyeti kendi oğullarına devrediyor, hükümranlık kaidelerinin hukuki esaslarını (türeyi) kuruyordu. Oğuz Han'ın üç büyük oğlu Boz-oklan teşkil eden Gün,

\footnotetext{
${ }^{46}$ Osman Turan, a.g.e, s. 283, 284.

${ }^{47}$ Osman Turan, a.g.e, 284.
} 
Ay ve Yıldız sağ tarafta bulunuyor ve kendilerine yay; sol kolda diğer üç oğlu Gök, Dağ ve Deniz'e yani Üç-oklara da ok veriyor ve bunları birincilere tabi kılıyordu. Oğuzların on iki sağ, on iki sol beyleri ve boyları bu esasa göre hâkimiyet hakkına sahip bulunuyordu. ${ }^{48}$.

Türk boyları hakkında önemli bilgiler edindiğimiz Göktürk yazıtlarında Türk hakanlarının pederanelik vasıfları hakkında şu önemli bilgiler geçmektedir: "Türk Tanrısı Türk milletinin adı ve sanı yok olmasın diye babam Kă̆an (Kutluğ) ile anam Hatun'u yükseltmiş; şimdi de beni tahta çıkarmıştır. Ben hali ve vakti yerinde bir millet üzerinde hükümdar olmadım. Aç ve çıplak halkın hanı oldum. Türk milleti için gündüz oturmadım, gece uyumadım; ölesiye çalıştım. Başka yerlere göçmüş ve bitkin olan halkı tekrar yurtlarına topladım. Milletin belini doğrultayım diye şimalde Oğuz iline, şarkta Kıtaylara, cenupta Çinlilere karşı on iki sefer yaptım. Tanrı yardım ettiği için olgun milleti dirilttim. Çıplak halkı giydirdim; yoksul halkı zengin ettim; nüfusu azalmış milleti çoğalttım. Türklerin başka milletler arasında mevkiini yükselttim" bilgileri verilmektedir ${ }^{49}$.

Söz konusu bu kadim Türk geleneği Osmanlı hükümdarları tarafından da tatbik edilmiştir. Osmanlı hükümdarları, kendi saraylarında ikindi vakti, halk gelsin yesin diye nöbet çaldırmışlardır50. Osmanlı'daki bu uygulamaya dair Tevârih-i Âl-i'de şu bilgiler geçmektedir: "II. Bayezid'in Ladende yakınında verdiği ziyaret vesilesiyle, o kadar çok yemek dă̆ıtıldı ki "ol yerün Türk- ü Türkmanı taşımadan üşendi"51.

\section{f) Siyasi Hakîmiyetin Meşruiyeti olarak Kut Düşüncesi}

Türk devletlerinde siyasi iktidarın kaynağı "Kut" olarak adlandırılan bir tabir ile ifade edilmekteydi. Hükümdar ile özdeştirilen Kut'un kan vasıtasıyla babadan oğula geçtiğine inanılmaktaydı. Türklerde hükümranlık telâkkisi karizmatik olup, hükümdarlık yetki ve kudreti Tanrı tarafından bahşedilmiş, yani kut'lanmıştır. Nitekim Mete'nin unvanı “Gök Tanrının, güneşin tahta çıkardığı Tanrı

\footnotetext{
${ }^{48}$ Osman Turan, a.g.e, s. 121.

${ }^{49}$ Osman Turan, Türk Cihan Hâkimiyeti Mefküresi Tarihi, s. 109.

${ }^{50}$ Halil İnalcık, Osmanlı Imparatorluğu Klasik Çă̆, s. 73.

${ }^{51}$ Mehmet Öz, “Osmanlı Kroniklerinde Oğuz-Türkmen İmgesi”, s. 283.
} 
Kut'u Tanhu", Atillâ'nın ise "Tanrının Kılıcı" idi. Göktürk hükümdarlarından Bilge Han, kendisinin hükümdar olmasını aynı ilâhî menşeye bağlamakta: "Türk Tanrısı Türk milletinin adı sanı yok olmasin diye babam kă̆an ile anamı tahtta oturttu. Ben de Tanrı irade ettiğ $i$ için, Kut'um olduğu için kă̆an oldum. Öte yandaki milletleri nizama soktuk. Tanrı güç verdiği için Türk askerleri kurt gibi, düşmanları koyun gibi idi" ifadelerini kullanmaktadir ${ }^{52}$.

Türklerin İslamiyeti kabûl etmesiyle birlikte İslami bir kimliğe dönüşen kut mefhumu Osmanlı zamanında özellikle Tursun Bey'in referanslarıyla II.Mehmed zamanında "Padişâh-ı ruy-ı zemin zillullah-i fi'l-arz"padişahın, Allah'1n yeryüzündeki gölgesi olduğu görüşüyle İslami bir motife dönüştürülmüştür. Bu doğrultuda Osmanlı hanedanlığ1 tebâsı önünde meşruiyetinin çizgilerini çizmiş ve kutsiyet atfedilen bu hanedanın erkek evlatlarının kanının dökülmesi yasaklanmıştır. Bu doğrultuda Osmanlı şehzâdelerinin öldürülmesinde yay kirişi kullanılmıştır.

\section{Toprakların Tâksimi Problemi}

Geleneksel Türk Devlet telâkkisi Türkistan bölgesinde M.Ö dönemlerden itibaren yağma düsturuna göre şekillenmiştir. Özellikle Orta Asya'da kurulan göçebe Türk Kağanlıklarının geleneksel feodal devlet verasetine göre, ele geçirilen topraklar, hükümdar ve ailesinin ortak malı görüşüne göre tâksim edilmekteydi. Bu geleneğe göre iki'li sistem teşkilatlanması ortaya çıkmış ve asıl hükümdar güneşin doğduğu taraf olan doğuda otururken, naibolan Yabgu ise ülkenin batı kısımlarını yönetmiştir. Geleneksel bir feodalite teşkilatlanması olan bu sistemin tezâhürlerine Osmanlı Devletinde de karşılaşmaktayız. Her ne kadar II. Mehmed'in çıkardığı kanunâmeyle, ülke hükümdar ve oğullarının ortak malıdır düsturuna çevrilerek feodal teşkilatlanma yerine daha merkeziyetçi bir konuma getirilmeye çalışılmış olsa bile, II. Mehmed'in verasetin sınırlarını çizdiği Kânuni Esasi'ye rağmen vefatından sonra şehzâdeleri II. Bayezid ve Cem Sultan arasındaki saltanat mücadeleleri esnasında devletin tekrardan eski ûsüllere göre taksim edilmesi teklifi ortaya çıkarılmıştır. Buna göre Cem Sultan, ağabeyi II. Bayezid'e, Anadolu ve Rum-eli olmak üzere, devleti aralarında taksim ederek mücadeleye nihayet vermeyi teklif etmiş, II. Bayezid ise bu teklife "Bu kişver-i Rûm bir

\footnotetext{
${ }^{52}$ Osman Turan, Türk Cihan Hâkimiyeti Mefküresi Tarihi, s. 249.
} 
ser-i pûş̂̀de-i arûs-i pür namustur ki iki dâmad hutbesine tâb götürmez" (Osmanlı Devleti öyle bir başı örtülü namuslu bir gelindir ki iki dam adın talebine taham m ül edemez " 'Arûs-i saltanat taksim kabul etmez" sözüyle karşılık veriris3.

Söz konusu veraset sistemi hakkındaki bir diğer örnek ise, Ankara savaşı sonrasında Emir Timur'un ölümü sonrası başa geçen oğlu Şâhruh'un, Osmanlı yöneticilerinden Çelebi Sultan Mehmed'e yazdığı bir mektupta: "Süleyman Beg ve İsa Beg ile mücâdele ettiğiniz ve Osmanlı töresince onları bu fâni dünyadan uzaklaştırdığııın haberini aldık. Ama biraderler arasında bu usûl İlhanî töresine münasip değildir" sözleriyle yaşanan taht mücadelesi kınanmaktaydı. Çelebi Sultan Mehmed ise Şahruh'a verdiği cevabında: "Osmanlı Pâdişâhları başlangıçtan beri tecrübeyi kendilerine rehber yapmışlar ve saltanatta ortaklığı kabûl etmemişlerdir. Gülistan sâhibi (Şâir Sa'dî)nin dediği gibi on derviş bir kilim üzerinde uyur; lâkin iki pâdişâh bir iklime sığmaz" sözleriyle Oğuz verasetinin Osmanlı dönemindeki akislerini aktarmış$\operatorname{tir}^{54}$.

Yukarıdaki bilgilere ek olarak yine Osmanlı kuruluş dönemindeki Yeniçerilerin Bektâşî geleneğine göre yetiştirildikleri ve "börk" giydikleri bilinmektedir ${ }^{55}$. Bununla birlikte davul, nevbet törenleri ve sefer sırasında ordulara iştirak eden mehteran bölükleri, II. Murad'ın sarayında Dede Korkut hikâyelerini okuyan ozanların, Kânuni döneminde seferlerde orduya moral aşılamak amacıyla Oğuz Han'ın destanının okutulması geleneği, Türkistan'dan gelen derviş ve âlimlerin İstanbul'da konaklama ihtiyacının karşılanması için Özbek tekkeleri yaptırılması. Bu vb. gelenekler, Osmanlı dönemindeki diğer Oğuz izlerinin yansımaları olarak karşımıza çıkmaktadir.

Sonuç olarak Osmanlı hanedanlığ kuruluş döneminden itibaren dönemin şartlarına göre şekillendirdikleri pragmatik yöntemlerle kısa sürede Bizans ve Anadolu Selçuklu devletlerinin yerine alternatif olmayı başarmışlardır. Osmanlı hâkimiyetinin kaynağının birçok taraftan beslendiği aşikârdır. Bunun içerisinde geleneksel Türk devlet telâkkisinin Osmanlılardaki tezahürleri olarak

\footnotetext{
${ }^{53}$ Osman Turan, a.g.e, s. 241.

${ }^{54}$ Osman Turan, a.g.e, s.241.

${ }^{55}$ Haldun Eroğlu, Osmanlılar Devlet ve Hâkimiyet, s.23.
} 
Oğuz(Türk) devlet geleneklerinin de klasik dönemde belirgin bir şekilde karşımıza çıkmaktadır.

\section{Kaynakça}

Bahadır Han, Ebulgazi, Şecere-i Terâkime:Türklerin Soy Kütüğü, Çev.Muharrem Ergin, Tercüman yay, Kervan Kitapçlık, Konya 1974.

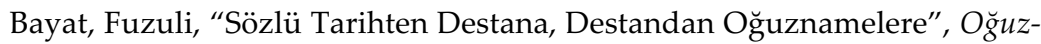
lar: Dilleri,Tarihleri ve Kültürleri, V. Uluslararası Türkiyat Araştırmaları Sempozyumu Bildirileri, Ankara 2015.

Bulduk, Üçler, “Osmanlı Beyliğinin Oluşumunda Oğuz/Türkmen Geleneğinin Yeri”, Osmanlı (Siyaset), Ankara 1999.

Çobanoğlu, Özkul," Batı Sibirya Türk Kültürü Tetkiklerine Göre Kayın Ağacinın Türk Mitolojisinde "Kutsal"laşmasının Maddi Kültürel Nedenleri" Orhon Yazıtlarının Bulunuşundan 120 Yıl Sonra Türklük Bilimi ve 21. Yüzyıl Konulu III. Uluslararası Türkiyat Araştırmaları Sempozyumu, Ankara 2010, s.245-247.

Ergin, Muharrem, Orhun Abideleri, T.D.K, Ankara 2011.

Esin, Emel, “Ordu: Türk Saray Mimarisinin XV. Yüzyıldan Önceki Tarihçesi", TBMM Milli Saraylar Sempozyumu, C.I, Ankara Kasım 1984.

Fazlullah, Reşidüddin, Câmiü't Tevârih(Selçuklu Devleti),Çev. Erkan Göksu, Hüseyin Güneş, Selenge yay, İstanbul 2010.

Göksu, Erkan, “Osmanlı Devleti'nin Kuruluşunda Gaza ve Türkmen(Oğuz) Ananelerinin Rolü Üzerine”, Oğuz Geleneğ $i$ Çerçevesinde Tarihten Günümüze Karakeçililer, Ed.İsmail Özçelik, Kırıkkale 2003.

Gömeç, Saadettin, Türk Destanlarına Giriş, Berikan Yayınevi, Ankara 2015.

İnalcık, Halil, Osmanlı Imparatorluğu Klâsik Çă̆ (1300-1600),Çev. Ruşen Sezer, Yapı Kredi Yay, İstanbul 2004.

“Osmanlı Türk Tarihçiliği Üzerine Notlar”,Çev.Bülent Arı, Uluslararası Askeri Tarih Dergisi, yay No:19, Ankara 2007.

Kafadar, Cemal, İki Cihan Arefesinde: Osmanlı Devleti'nin Kuruluşu, Çev.Ceren Çırkın, Editör: Mehmet Öz, Birleşik yay, İstanbul 2010.

Köprülü, M.Fuad, “Osmanlı İmparatorluğunun Etnik Menşei Meseleleri”, Belleten, C. VII/28, TTK, Ankara1943. İslam ve Türk Hukuk Araştırmaları ve Vakıf Müesesesi, Akçă̆ yay, Ankara 2005 Osmanlı'nın Etnik Kökeni, Kaynak yay, İstanbul 1999.

“Osmanlı Devleti'nin Kuruluş ve Gelişmesindeki İtici Güçler", Osmanl1(Siyaset).

Mahmud, Kaşgarlı, Divânü Lügat'it Türk, Çev. Besim Atalay, TTK, Ankara 2006. 
Öztürk, Yücel, “Osmanlı Devleti'nin Kuruluşu Hakkında Bazı Görüşler”, Kuruluş ve Çöküş Süreçlerinde Türk Devletleri Sempozyumu Bildirileri, Sakarya Üniversitesi yay.No 52, Sakarya 2008.

Sümer, Faruk, “Kayı”, İslam Ansiklopedisi, C.XXV, TDVA, Ankara 2002.

Faruk, O ğuzlar(Türkmenler):Tarihleri-Boy Teşkilatı-Destanları, Türk Dünyası Araştırmaları Vakfı, İstanbul 1999.

Togan, Zeki Velidi, Oğuz Destanı(Reşideddin Oğuznamesi Tercüme ve Tahlili, Enderun Kitabevi, İstanbul 1982.

Turan, Osman, Türk Cihan Hâkimiyeti Mefküresi Tarihi, Ötüken yay, İstanbul 2013.

Heywood, Colin.J.,“Osmanlı Devleti'nin Kuruluş Problemi Yeni Hipotez Hakkında Bazı Düşünceler",Osmanlı(Siyaset), Ankara 1999.

Eroğlu, Haldun, Osmanlılar: Devlet ve Hâkimiyet, Bilge Kültür Sanat yay, İstanbul 2016.

“Osmanlıda İktidarın Değişim Süreci ve Meşruiyet Sorunu", Ankara Üniversitesi Dil ve Tarih Coğrafya Fakültesi Dergisi, S.2,Ankara 2004.

Öz, Mehmet, “İlk Osmanlı Kroniklerinde Oğuz Türkmen İmgesi”, Oğuzlar; Dilleri, Kültürleri, Tarihi, V. Hacettepe Türkiyat Araştırmaları Sempozyumu, Ankara 2015.

Taşbaş, Erdal, “Klasik Dönem Osmanlı Tarih Yazarları ve Eserlerine Kısa Bir Bakış",Mediterranean Journal of Humanities,S. I/2, Antalya 2011.

Gündüz, Tufan, "Osmanlı Tarih Yazıcılığı'nda Türk ve Türkmen İmajı”, OSMANLI, Editörler: Kemal Çiçek-Cem Oğuz, c. VII, Ankara 1999. 